\title{
Hydrovisbreaking of Cerro Negro Crude Oil
}

\author{
R. Galiasso*, J. A. Salazar, R. Blanco, and A. Morales \\ INTEVEP, S.A., P.O. BOX 76343, Caracas 1070A, Venezuela
}

(Received December 27, 1983)

\begin{abstract}
A hydrovisbreaking process was developed in order to upgrade heavy oil such as that from the Orinoco Oil Belt, which is characterized by high contents of metals, asphaltenes and residuum. The hydroconversion stage was carried out in a coil type reactor followed by a soaker or hydrogenating reactor. Economic studies show that this process is competitive with other upgrading technologies.
\end{abstract}

\section{Introduction}

In a high conversion refinery, hydrogen rich product (syncrude) is produced from a relatively hydrogen poor feedstock. Basically, this can be done either by the addition of hydrogen (hydroprocessing) or by the elimination of carbon (coking) or asphaltene. A coking scheme produces medium quality upgraded distillates package but simultaneously downgrades part of the feedstock to coke. The deasphalting route produces a low value liquid product and high amount of solid material with high metal content.

A hydroprocessing scheme produces a large quantity of marketable products from a given quantity of low quality residuum and could, therefore, be the better choice in cases where crude conservation or high product cost is desired instead of stockpiling solids.

Catalytic hydroprocessing, like $\mathrm{H}-\mathrm{Oil}$ or similar processes, uses a large volume of catalysts in a high severity reactor and complex technologies, but it could treat residuals containing large amounts of metals asphaltenes and residuum. A low metal, sulphur and nondistillable material is obtained with high investment and operating cost.

Hydrovisbreaking process was used during World War II by the Germans and now several processes similar to this one are offered. Some of them use a Hydrogen Donor Solvent ${ }^{2), 3)}$, or high hydrogen operating pressure ${ }^{1}$, or special catalyst ${ }^{4) \sim 7}$ ). This work deals with the bench scale development of a new hydrovisbreaking process, using an inexpensive additive to control product quality and liquid yield.

* To whom correspondence should be addressed.

\section{Experimental}

Research was perfomed by using two types of units. Figure 1 shows a simplified scheme for unit $\mathrm{A}$, which uses a coil and a hydrogenation reactor, and unit $\mathrm{B}$ which uses a coil and a soaker reactor. Liquid and additives are pumped through a preheater to obtain the reaction temperature at the inlet of the coil reactor. The operating conditions for the coil are maintained constant (see Table 3) and the severity is changed in the hydrogenation or in the soaker reactor. Hydrogen is also fed to the coil reactor at a high $\mathrm{H}_{2}$ to hydrocarbon ratio to obtain the required fluid dynamics in the reactor. The coil outlet stream is fed directly to an hydrogenation reactor (down flow) or a soaker reactor (see in Table 3, the reactors' operating conditions). The liquid product from the reaction zone is separated in a hot separator (high pressure high temperature) or in a cold separator (high pressure low temperature). For high conversion operation a special decanting stage is used to purify the liquid product, but disclosure on this is not made here. Conventional ASTM analyses were performed to determine the properties of the liquid product and fractions. Stability and compatibility analyses were performed to follow coking reactions. Deasphalting with $\mathrm{C}_{3}$ and $\mathrm{C}_{7}$ solvents was performed on the $500^{\circ} \mathrm{C}^{+}$cut so as to distinguish asphaltene, resins and oil, which were analyzed by NMR to determine aromatic structures. Elemental analysis, TGA and microscopic determination were also carried out.

At low severity, two different residence times were used in the hydrogenation reactor. At high severity, two different temperatures in the soaker reactor were employed (Table 3). 


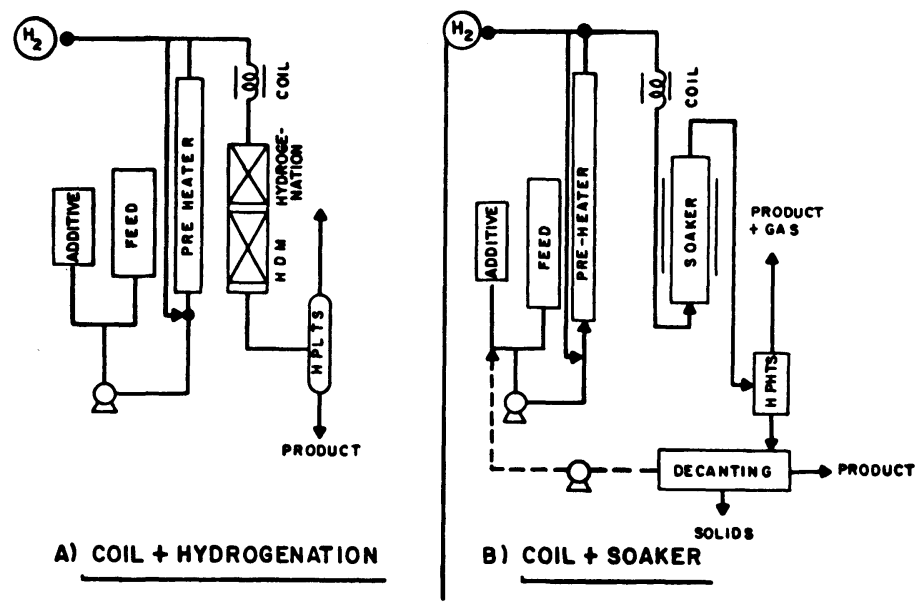

Fig. 1 Equipments Used (Bench Scale)

Table 1 Cerro Negro Grude Oil Characterization

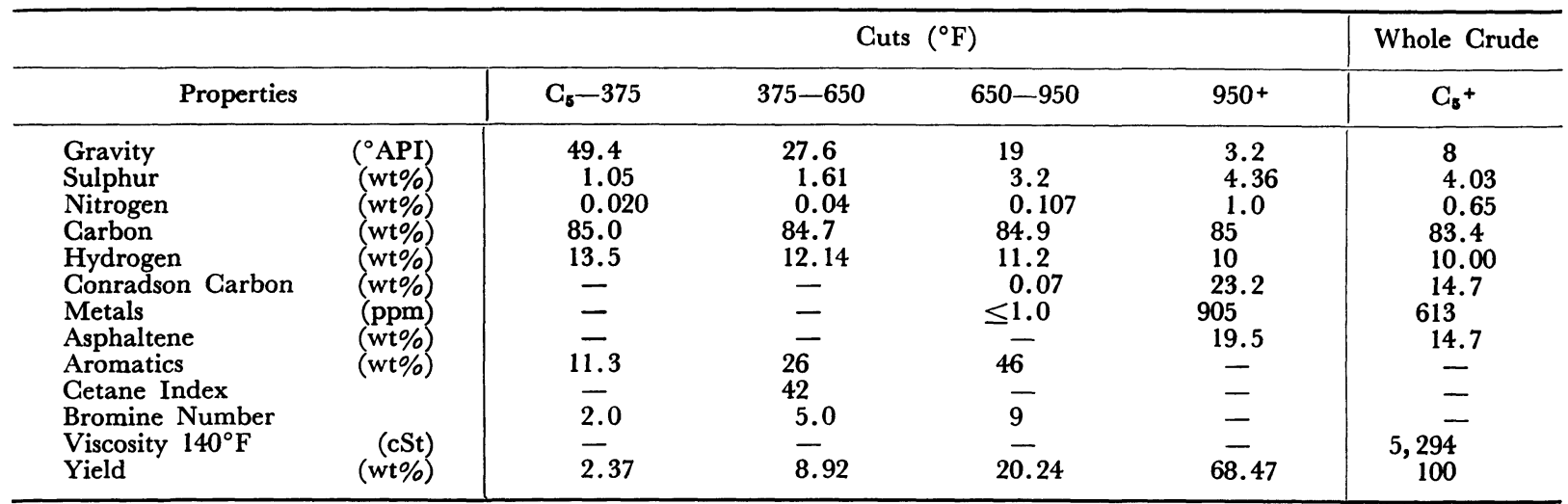

The feeds were whole Cerro Negro Crude Oil (see properties in Table 1 ) or its atmospheric residuum $\left(650^{\circ} \mathrm{F}^{+}\right)-$(see properties in Table 6).

The effect of additives was studied in a discontinuous reactor (STDR) operating at conditions equivalent to those of a soaker reactor.

\section{Results and Discussion}

\subsection{Feed Characterization}

The results of Cerro Negro Grude Oil analysis are shown in Tables $\mathbf{1}$ and 2. This is a young extra heavy crude oil with high amounts of metals (690 $\mathrm{ppm})$, asphaltenes $(12 \mathrm{wt} \%$ ) and residuum $(60 \mathrm{wt} \%)$. This material is not economically transportable and requires a minimum upgrading to decrease the viscosity to $120 \mathrm{cSt}$ at $38^{\circ} \mathrm{C}$. The vacuum residuum properties indicate an aromatic type crude with low $\mathrm{H} / \mathrm{C}$ ratio, high nitrogen and sulpfur contents. Differential thermal analysis of Cerro Negro asphaltenes shows that during pyrolysis they lose a higher amount of light ends than Boscan asphaltenes. Table 2 contains the $H / C$ and $N / C$ ratios for asphaltene, resins and the oil. Metals
Table 2 Asphaltene, Resins and Oil in $500^{\circ} \mathrm{C}$ Cut of Virgin (Cerro Negro)

\begin{tabular}{|c|c|c|c|c|}
\hline \multicolumn{2}{|c|}{ Properties } & $\begin{array}{c}\text { Asphaltene } \\
\left(\mathrm{C}_{\mathbf{q}}\right)\end{array}$ & $\begin{array}{l}\text { Resins } \\
\left(\mathrm{C}_{3}-\mathrm{C}_{7}\right)\end{array}$ & Oil \\
\hline $\begin{array}{l}\text { Yield } \\
\text { Carbon } \\
\text { Sulphur } \\
\text { Hydrogen } \\
\text { Nitrogen } \\
\text { Vanadium } \\
\text { Nickel } \\
\text { Aromaticity } \\
\text { Arom. Per. }\end{array}$ & $\begin{array}{c}(\mathrm{wt} \%) \\
(\mathrm{wt} \%) \\
(\mathrm{wt} \%) \\
(\mathrm{wt} \%) \\
(\mathrm{wt} \%) \\
(\mathrm{ppm}) \\
(\mathrm{ppm}) \\
\left(\mathrm{f}_{\mathrm{a}}\right)^{*} \\
\text { Mol.* }^{*}\end{array}$ & $\begin{array}{r}18.5 \\
85.0 \\
4.03 \\
8.8 \\
1.4 \\
2,500 \\
610 \\
0.44 \\
16\end{array}$ & $\begin{array}{r}30.3 \\
84.6 \\
4.67 \\
9.5 \\
1.137 \\
598 \\
130 \\
0.32 \\
6\end{array}$ & $\begin{array}{r}51.2 \\
84.8 \\
4.35 \\
10.5 \\
0.768 \\
173 \\
8 \\
0.21 \\
2\end{array}$ \\
\hline
\end{tabular}

* by NMR analysis

are mainly present in the so called "asphaltene" structures which contain intermediate amounts of porphyrins (ETHIO and DPDP). The aromaticity degree is 0.44 for asphaltene, 0.32 for resins and 0.21 for oil (The asphaltene described here contains about $40 \%$ of resins). $\mathrm{V} / \mathrm{Ni}$ ratios are 4 for asphaltene, 4.6 for resins and 2 for oil. The aromatic rings per molecule are 16, 6 and 2, and molecular weights obtained on asphaltene, resins and oil are 2,000, 1,250 and 1,000 (VPO), respectively.

The ratio of acid to base content for the vacuum 
Table 3 Operating Conditions at Bench Scale

\begin{tabular}{|c|c|c|c|c|}
\hline \multirow{2}{*}{ Conditions } & \multicolumn{4}{|c|}{ Reactions } \\
\hline & Coil & Hydrogenation I & Hydrogenation I+HDM & Soaker \\
\hline $\begin{array}{l}\text { Temperature }\left({ }^{\circ} \mathrm{C}\right) \\
\text { Pressure }\left(10^{8} \cdot \mathrm{Pa}\right) \\
\mathrm{H}_{2} / \mathrm{HC} \\
\text { Relative Residence Time } \\
\text { Catalyst } \\
\text { Additive/HC (vol\%) }\end{array}$ & $\begin{array}{r}480 \\
1.03 \\
680 \\
0.02 \\
-10\end{array}$ & $\begin{array}{c}400 \\
1.03 \\
680 \\
0.2 \\
\text { INT-2 } \\
10\end{array}$ & $\begin{array}{c}400 \\
1.03 \\
1,500 \\
0.4 \\
\text { INT-2/3 } \\
10\end{array}$ & $\begin{array}{c}430-450 \\
1.2 / 1.2 \\
1,500 / 1,500 \\
1.0 \\
\frac{10}{10}\end{array}$ \\
\hline Severity & \multicolumn{2}{|r|}{ I } & II & III \\
\hline
\end{tabular}

HDM : Hydrodemetallization

residuum is $1.2(20 / 16.6)$. Other feedstock characterizations were previously reported by Lubkowitz et al. ${ }^{8)}$ These results are from a joint research effort made by Intevep (Venezuela) and DOE (USA).

\subsection{Low Severity Hydrovisbreaking}

The hydrovisbreaking process was performed at low severity using a coil reactor followed by a hydrogenation reactor. The preliminary results indicate that the severity used in the coil reactor must be controlled in order to obtain stable products. The thermal reaction occurred in the liquid phase, which is mainly segregated from the gas phase, and it moves down flow attached to $30 \%$ of the internal coil wall. The heating rate and wall temperatures must be lower than $500^{\circ} \mathrm{C}$ to avoid "dry points" where coking reactions could take place. Without additives and at a high hydrogen partial pressure, the coil reactor could not be operated for a long period of time. Using additives and high $\mathrm{H}_{2}$ partial pressure, a normal operation is achieved. In the hydrogenation reactor the unsaturates formed during the hydroconversion stage are saturated, and a stable final product is obtained. Nevertheless the level used in coil reactor must be limited up to $30 \%$ of residuum conversion to avoid plugging

Table 4 Properties of INTEVEP-2 Hydrogenation Catalyst

\begin{tabular}{|c|c|c|}
\hline Properties & Fresh & Spent (25 DOS) \\
\hline $\begin{array}{l}\mathrm{MoO}_{3}(\mathrm{wt} \%) \\
\mathrm{NiO}(\mathrm{wt} \%) \\
\mathrm{V}_{2} \mathrm{O}_{3}(\mathrm{wt} \%)\end{array}$ & $\begin{array}{l}8.1 \\
1.73 \\
-\end{array}$ & $\begin{array}{l}8.1^{*} \\
4.6^{*} \\
7.6^{*}\end{array}$ \\
\hline $\begin{array}{l}\text { Particle Size (inch) } \\
\text { Pore Volume }\left(\mathrm{cm}^{3} / \mathrm{g}\right) \\
\text { Surface Area }\left(\mathrm{cm}^{2} / \mathrm{g}\right) \\
\text { Pore Diameter }(\AA) \\
\text { Mechanical Strength }(\mathrm{kg} / \mathrm{mm}) \\
\text { Coke (wt } \%) \\
\text { Vanadium Distribution } \\
\text { Carbon between Particles }\end{array}$ & $\begin{array}{l}1 / 32 \\
0.67 \\
285 \\
151 \\
3.5 \\
- \\
\text { NIL }\end{array}$ & $\begin{array}{c}1 / 32 \\
0.35 \\
70 \\
90 \\
5.2 \\
18 \\
\text { Homogeneous } \\
\text { NIL }\end{array}$ \\
\hline
\end{tabular}

石油学会誌 Sekiyu Gakkaishi, Vol. 28，No. 1，1985 problems in the catalytic reactor. The operating conditions for the coil and hydrogenation reactors for two typical runs, are shown in Table 3, and the properties of the catalyst are shown in Table 4. The hydrogenating catalyst (INT-2) has a special pore distribution that allows penetration of the cracked molecules in the pores but limits asphaltene diffusion (pore excluding type). Using this catalyst, an intermediate rate of demetallization is achieved. Carbon deposition is limited to $18 \%$ and it remains constant after 25 days of operation. The additive used slightly modifies the physicochemical properties of the catalyst and it limits the carbon formation. INTEVEP 3 is a conventional HDM catalyst (see Ref. 9).

The results obtained with Severity I and II are presented in Table 5. In this case the whole Cerro Negro crude was used as feedstock. In the coil stage, a $30 \%$ conversion of the $500^{\circ} \mathrm{C}^{+}$fraction takes place. This heavy material is mainly transformed into Diesel (20/25\% by wt). Metals, nitrogen, and sulphur are principally removed in the hydrogenating stage. The liquid yield is $96.0 /$ $96.5 \%$ by wt $(99.8 / 100.5 \%$ by vol $)$ and the hydrogen consumption obtained is $70 / 162 \mathrm{Nm}^{3} / \mathrm{t} \quad(70 \%$ of which is used for production of $\mathrm{C}_{1}-\mathrm{C}_{4}$ ).

The summary of conversions is shown in Table 7. The main result is a higher asphaltene, metals and sulphur removal in the catalytic HDM reactor (Severity II Catalyst INT-3) when comparing with those results obtained in the hydrogenation reactor. The catalytic reactor slightly increases the coil conversion of the heavy material $(30 \rightarrow 38 / 43 \%)$. A sharp decrease in viscosity is obtained for both severity levels.

In order to test the operability of the system, a 25 day-continuous test was performed. The relative value of viscosity, sulphur, density and metals can be seen in Fig. 2. No appreciable decline in activity was observed. The catalyst properties after 25 days of use are shown in Table 4 (spent cata- 
Table 5 Low Severity Hydroconversion (Coil+Hydrogenation) (See Operating Conditions in Table 3)

\begin{tabular}{|c|c|c|c|}
\hline Properties & Feed & Severity I* & Severity II \\
\hline 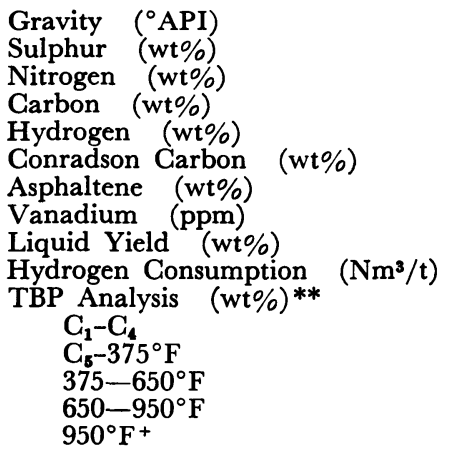 & $\begin{array}{l}8.0 \\
3.55 \\
0.6 \\
83.6 \\
10.22 \\
13.66 \\
12.15 \\
438 \\
100 \\
- \\
- \\
\overline{10} \\
30 \\
60\end{array}$ & $\begin{array}{c}13.8 \\
2.06 \\
0.65 \\
83.32 \\
11.24 \\
10.5 \\
10.5 \\
338 \\
96.5 \\
70 \\
\\
2.3 \\
3.37 \\
15.44 \\
41.00 \\
36.65\end{array}$ & $\begin{array}{c}16.0 \\
1.0 \\
0.5 \\
82.79 \\
11.4 \\
7.77 \\
4.33 \\
138 \\
96 \\
162 \\
\\
2.7 \\
4.9 \\
23.14 \\
33.6 \\
34.17\end{array}$ \\
\hline Stability & good & good & good \\
\hline
\end{tabular}

* 25 days on stream $* *$ Based on feed

Table 6 High Severity Hydroconversion (Coil+Soaker) (See Fig. 1B)

\begin{tabular}{|c|c|c|c|}
\hline \multirow[b]{2}{*}{ Properties } & \multirow[b]{2}{*}{ Feed } & Severity III & Severity IV \\
\hline & & Soaker Temp. $\left({ }^{\circ} \mathrm{C}\right)$ & $\left({ }^{\circ} \mathrm{G}\right)_{450}$ \\
\hline $\begin{array}{l}\text { Gravity }\left({ }^{\circ} \mathrm{API}\right) \\
\text { Sulphur }(\mathrm{wt} \%) \\
\text { Carbon } \quad(\mathrm{wt} \%) \\
\text { Hydrogen (wt } \%) \\
\text { Nitrogen (ppm) } \\
\text { Conradson Carbon (wt } \%) \\
\text { Asphaltene (wt } \%) \\
\text { Liquid Yield (wt } \%) \\
\text { Hydrogen Consumption } \quad\left(\mathrm{Nm}^{3} / \mathrm{t}\right) \\
\text { TBP Analysis (wt } \%) \\
\quad \mathrm{C}_{1}-\mathrm{C}_{4} \\
\quad \mathrm{C}_{5}-375^{\circ} \mathrm{F} \\
\quad 375-650^{\circ} \mathrm{F} \\
\quad 650-950^{\circ} \mathrm{F} \\
\quad 950^{\circ} \mathrm{F}+ \\
\text { Stability }\end{array}$ & $\begin{array}{c}5.7 \\
4.32 \\
83.51 \\
9.7 \\
7,268 \\
17.05 \\
16.67 \\
100 \\
- \\
- \\
1.28 \\
- \\
20.05 \\
78.67 \\
\text { good (L3) }\end{array}$ & $\begin{array}{c}18 \\
2.8 \\
83.83 \\
10.62 \\
4,500 \\
8.7 \\
9.5 \\
95.8 \\
125.0 \\
\\
3.5 \\
9 \\
25 \\
36 \\
26 \\
\text { bad (-) }\end{array}$ & $\begin{array}{c}20.2 \\
3.31 \\
83.85 \\
10.67 \\
3,298 \\
8.9 \\
8.72 \\
96.0 \\
149.95 \\
4.7 \\
13.34 \\
29.09 \\
37.25 \\
16.40 \\
\text { bad }(-)\end{array}$ \\
\hline Stability after decanting & - & good (L3) & good (L3) \\
\hline
\end{tabular}

lyst). The vanadium accumulation was $7 \%$ by weight on the basis of fresh catalyst and the vanadium distribution through particle radius, measured by microprobe X-ray analysis, is nearly homogeneous. The carbon deposited on the catalyst eliminates $50 \%$ of the pore volume and $70 \%$ of the surface area without affecting the steadystate activity obtained after 2 days of operation of the plant.

Using Severity I or II, the syncrude quality produced is suitable for sale as a medium quality transportable heavy oil $\left(16^{\circ} \mathrm{API}, 1 \%\right.$ of sulphur, $140 \mathrm{ppm}$ of vanadium). The required investment is moderate (similar to GULF HDS process) and the process uses a conventional well-proven technology such as a visbreaking coil reactor and hydrogenation + demetallization reactors.

\subsection{High Severity Hydrovisbreaking}

The preliminary studies carried out with the coil reactor alone demonstrated that high conversion could not be achieved only with this unit because the product unstability became so great that the hydrogenating reactor was soon plugged up. The fundamental reason for this phenomenon is that the high rate of pyrolysis of Cerro Negro resins in a relatively poor hydrogen contact regime, such as that existing in the coil, produces an insoluble material which is formed by dealkylation reactions of resins and degraded asphaltenes.

This problem can be overcome by using the same low severity level for the coil as for the previous scheme, but carrying out additional hydrovisbreaking with a bubble clumn type reactor, instead of using a catalytic reactor. Two severity levels were studied using Unit B (See Fig. 1). The product from the two hydrovisbreaking reactors is 


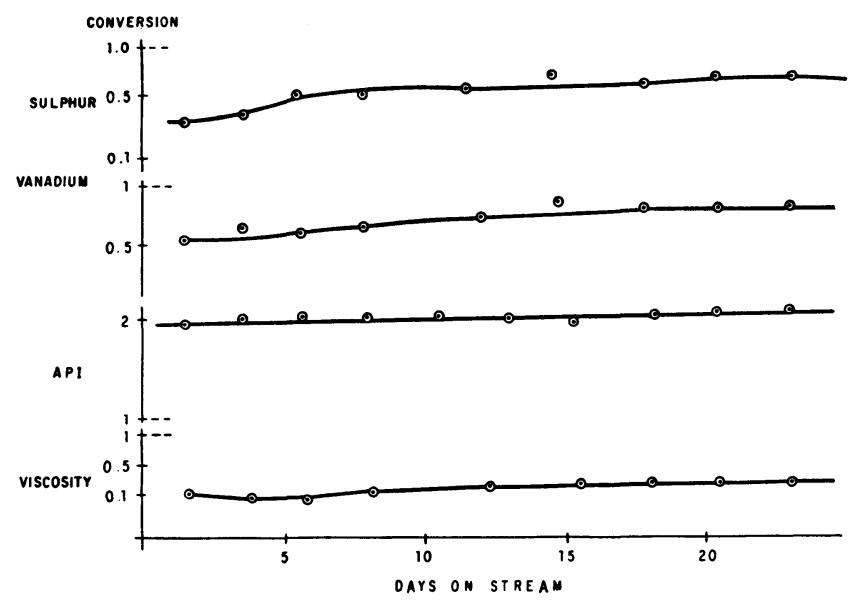

Fig. 2 Hydroconversion + Hydrogenation Stability Initial Value (Feed)-Actual Value (Product)/Initial Value (Feed)

separated in a HPHTS (high pressure high temperature). The liquid phase which contains the major part of VGO and residuum is treated in a special solid decanter unit. The insoluble "asphaltenic" material (Carboides and Coke) formed during the reaction is eliminated in this stage, and the unconverted bottom is recycled to the hydrovisbreaking zone. The analysis of the product from the hydroconversion stage (before decanting) is shown in Table 6 for two typical soaker temperatures (430 and $450^{\circ} \mathrm{C}$ ). The feedstock used was a $5^{\circ} \mathrm{API}$ atmospheric residuum. The liquid yields obtained were $96 \%$ by weight or $104 \%$ by volume. Hydrogen consumptions were 125 and $150 \mathrm{Nm}^{3} / \mathrm{t}$ for 67 and $79 \%$ conversions of the $500^{\circ} \mathrm{G}^{+}$fraction, respectively. The other conversions are shown in Table 7. It can be noted that the asphaltene and Conradson Carbon variations were about 50 and $45 \%$, respectively. Severity IV is achieved at higher temperature with higher hydrogenation reaction than Severity III. If higher residence time is used at the same temperature $\left(430^{\circ} \mathrm{C}\right)$, nearly the same hydrogenation takes place. Long term operation (45 days on stream) showed a constant product quality, which indicated that a high quality syncrude could be obtained with a smooth bench scale operation.

The qualities of the cuts obtained with Severity IV are shown in Table 9. Comparing Table 1 with Table 9, it can be seen that:

- Naphtha fraction produced is heavier and it contains a lower amount of sulphur, a higher content of aromatics and a higher content of nitrogen than that of the virgin feedstock.

- Diesel Oil produced has higher sulphur and nitrogen contents than those of the virgin fe- edstock.

- VGO fraction produced has higher nitrogen, Conradson Carbon and insaturates contents than those of the virgin VGO. The former is also heavier than the latter.

- Vacuum residuum produced has substantially different properties than the original. It has higher sulphur, nitrogen, Conradson Carbon, asphaltene and metal contents, and lower hydrogen content than those obtained in the virgin feedstock.

Analyses of the asphaltene, resins and oil present in the $500^{\circ} \mathrm{C}^{+}$fraction were carried out in order to explain the reaction mechanism in the visbroken

Table 7 Conversion Obtained in Hydrovisbreaking

\begin{tabular}{l|cccc}
\hline \multicolumn{1}{c|}{ Properties \% } & SEV I & SEV II & SEV III & SEV IV \\
\hline$\Delta 5^{\circ} \mathrm{C}^{+}$ & 38.9 & 43.05 & 67.0 & 79.0 \\
$\Delta \mathrm{CRC}^{-}$ & 25.82 & 45.4 & 51.0 & 47.8 \\
$\Delta$ Asphaltene & 16.2 & 65.8 & 45.29 & 49.8 \\
$\Delta$ Sulphur & 44.0 & 72.9 & 37.77 & 26.4 \\
$\Delta$ Metals & 25.53 & 69.7 & - & - \\
$\Delta$ Hydrogen (-) & 9.9 & 11.54 & 9.4 & 10.2 \\
$\Delta$ Nitrogen & 10.4 & 31.4 & 38.4 & 57.7 \\
$\Delta$ Viscosity & 92.0 & 98.0 & 98 & $\geq 98$ \\
\hline \multicolumn{5}{c}{ Initial Value - Final Value $\times$ Liquid Yield } \\
\multicolumn{5}{c}{ Initial Value }
\end{tabular}

Table 8 Properties of Asphaltene, Resins and Oil in $500^{\circ} \mathrm{C}+$ (Hydrovisbroken)*

\begin{tabular}{|c|c|c|c|c|}
\hline \multicolumn{2}{|c|}{ Properties } & Asphaltene & Resins & Oil \\
\hline Yield & $(\mathrm{wt} \%)$ & 35.8 & 7 & 67.2 \\
\hline Carbon & $(\mathrm{wt} \%)$ & 86.21 & 85.9 & 86.5 \\
\hline Sulphur & $(\mathrm{wt} \%)$ & 4.6 & 5.2 & 5.3 \\
\hline Hydrogen & (wt $\%)$ & 7.8 & 8.1 & 8.9 \\
\hline Nitrogen & (ppm) & 15,800 & 3,600 & 8,118 \\
\hline Vanadium & (ppm) & 7,600 & 930 & 580 \\
\hline Nickel & (ppm) & 1,010 & 87 & - \\
\hline Aromaticit & $\left(f_{a}\right) * *$ & 0.68 & 0.45 & 0.40 \\
\hline Arom/Mol & & 12 & 10 & 3 \\
\hline
\end{tabular}


Table 9 Properties of the Cuts Obtained at Severity IV

\begin{tabular}{|c|c|c|c|c|c|}
\hline \multirow{2}{*}{ Properties } & & \multicolumn{4}{|c|}{ Cuts } \\
\hline & & $\mathrm{C}_{5}-375^{\circ} \mathrm{F}$ & $375-650^{\circ} \mathrm{F}$ & $650-950^{\circ} \mathrm{F}$ & $950^{\circ} \mathrm{F}^{+}$ \\
\hline $\begin{array}{l}\text { Gravity } \\
\text { Sulphur } \\
\text { Garbon } \\
\text { Hydrogen } \\
\text { Nitrogen } \\
\text { Conradson Carbon } \\
\text { Asphaltene } \\
\text { Aromatics } \\
\text { Cetane Index } \\
\text { Bromine Number } \\
\text { Metals }\end{array}$ & $\begin{array}{l}\left({ }^{\circ} \mathrm{API}\right) \\
(\mathrm{wt} \%) \\
(\mathrm{wt} \%) \\
(\mathrm{wt} \%) \\
(\mathrm{wt} \%) \\
(\mathrm{wt} \%) \\
(\mathrm{wt} \%) \\
(\mathrm{wt} \%) \\
\\
\\
(\mathrm{ppm})\end{array}$ & $\begin{array}{l}40.8 \\
0.77 \\
84.3 \\
13.3 \\
0.0094 \\
- \\
23.2 \\
- \\
14\end{array}$ & $\begin{array}{l}26.6 \\
2.01 \\
84.8 \\
12.0 \\
0.0481 \\
0.05 \\
- \\
20 \\
41 \\
9 \\
-\end{array}$ & $\begin{array}{l}17 \\
3.1 \\
86.00 \\
11.01 \\
0.2595 \\
0.27 \\
\frac{-}{25} \\
10 \\
-\end{array}$ & $\begin{array}{c}1.2 \\
6.2 \\
87.1 \\
8.8 \\
1.07 \\
45.0 \\
51.03 \\
= \\
- \\
2,381.6\end{array}$ \\
\hline
\end{tabular}

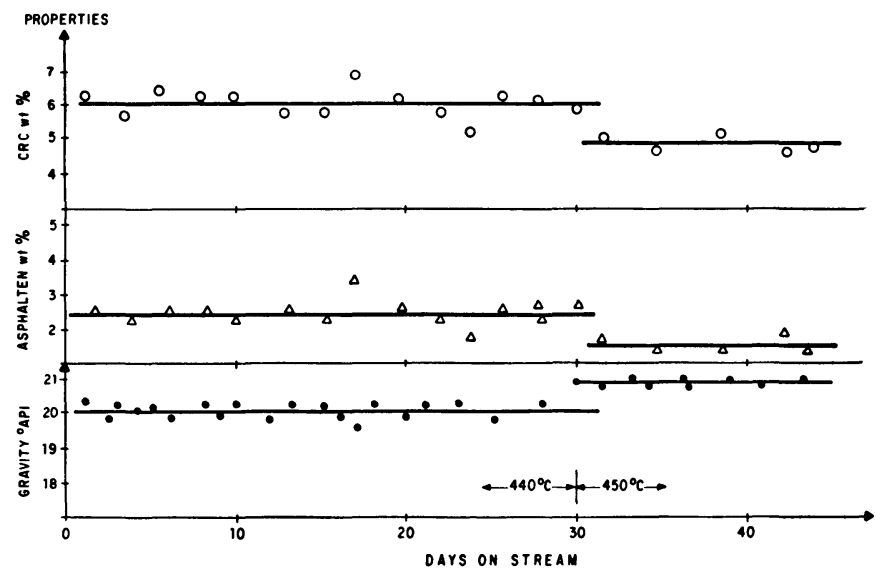

Fig. 3 High Severity Process (IV) Stability

material obtained at Severity III. The changes of the $500^{\circ} \mathrm{C}^{+}$material can be studied using the data presented in Tables 2 and 8. After reaction, the "asphaltenes" contain higher amounts of sulphur, carbon, nitrogen, metals, aromatics and xylene insoluble materials than the original asphaltenes. The molecular weight is now 1,000 (VPO) and the insoluble material has $30 \%$ (by wt) of metals. Microscopic analysis shows a turbostratic structure like that of coke and it reveals an average particle diameter below 10 microns.

Hydrovisbroken resins obtained are only $7 \%$ of the total material, which indicates that the major part of the resins originally present was transformed. Molecular weight is 750 instead of 1,250. Higher sulphur, nitrogen, metals and aromatics contents and a lower hydrogen content and Vanadium to Nickel ratio are observed in the product. The number of aromatic ring per molecule is now 6 instead of 10 .

Oil in the hydrovisbreaking $500^{\circ} \mathrm{C}^{+}$fraction has higher sulphur, nitrogen, vanadium, nickel, aromatics and carbon contents than the original oil. Porphyrin type molecules are now present in the oil and the molecular weight is 750 (VPO).
This indicates that asphaltenes and resins are transformed to some extent into oil, transferring metal and nitrogen as porphyrins. The following reaction scheme could be adopted for hydrovisbreaking reactions :

Primary Cracking

a) Asphaltene Cracking $\stackrel{\mathbf{H}_{\mathbf{2}}}{\longrightarrow}$ Distillates

+ Condensated Asphaltenes + Gas + Oil

b) Condensated Asphaltene $\stackrel{\mathrm{H}_{2}}{\longrightarrow}$ Gas+Coke

c) Resins $\stackrel{\mathrm{H}_{2}}{\longrightarrow}$ Distillates + Asphaltenes + Gas + Oil

d) $\mathrm{Oil} \stackrel{\mathrm{H}_{2}}{\longrightarrow}$ Distillates + Resins + Gas

Secondary Cracking

e) Distillates $\stackrel{\mathrm{H}_{2}}{\longrightarrow}$ Light Distillates + Gas

The destruction of asphaltene micelles and resins to give some carboide structure and subsequently coke, produces a poor quality residuum, but does not interfere with the normal operation of the soaker reactor. Using high linear gas velocity in the bubble column type reactor, the pitch and the insoluble material are carried out of the reactor and it operates without solid accumulation. The solid material is then separated from the reactor product in the decanter stage and the liquid from 
Table 10 Effects of the Homogeneous Additive Used

\begin{tabular}{l|cc}
\hline \multicolumn{1}{c|}{ Properties } & With Additive & Without Additive \\
\hline Gas Yield (wt $\%$ ) & 4.4 & 7.83 \\
Xylene Insoluble & 0.78 & 2.32 \\
$\Delta 500^{\circ} \mathrm{C}^{+}$ & 66 & 58 \\
$\Delta$ Conradson Carbon & 42 & 11 \\
Hydrogen & -0.09 & +0.07 \\
Asphaltene & 60.9 & 65.45 \\
$\mathrm{G}_{1}+\mathrm{C}_{2} /$ Total Gas & 0.26 & 0.46 \\
$\mathrm{C}_{\mathrm{n}}^{\mathrm{E}} /$ Total Gas & 0.03 & 0.08 \\
Naphtha/Distillates & 11.2 & 14.0 \\
Stability (HFT) & 1.7 & 3.9 \\
\hline
\end{tabular}

$$
\Delta=\left(\frac{\text { Initial Value }- \text { Final Value }}{\text { Initial Value }}\right) \times 100
$$

the unconverted bottom is recycled or sold as fuel oil.

\subsection{Additive Effect}

A special test was carried out in an autoclave at the same severity level as that used for the soaker reactor to demostrate the effect of an additive. Table 10 shows the results obtained. The use of the additive increases the $500^{\circ} \mathrm{C}^{+}$, Asphaltene and Conradson Carbon conversion. At the same time, it reduces gas yields and insoluble material formation, changes the product distribution yielding a lower, amount of naphtha and a higher amount of Diesel Oil.

The rate of hydrogenation reaction which takes place in the liquid and gas phases is improved by the additive, as can be observed from the total hydrogen in the syncrude as well as from the amount of unsaturates in distillates (low bromine number) and gases.

According to these results, it is possible to speculate that the additive plays an important role in the reaction $e$ (secondary cracking of distillates) reducing the breakdown of Diesel and Gasoline fractions. Since $90 \%$ by volume of the additive is in the gas phase, it could be assumed that a dilution effect would be present. Nevertheless, using inert gas $\left(\mathrm{N}_{2}\right)$ and using the same hydrogen partial pressure (nearly the same gas holdup also) the equivalent phenomenon was not observed as when using the additive. The quality of the residuum is sharply affected by the additive by reducing the amount of xylene insoluble material, and by increasing the stability of the sample and the molecular weight of the asphaltene. These effects indicate more of a chemical action than a physical one. Probably the additive interferes with reaction $b$ (condensate asphaltene degradation) and improves reactions $a$, $c$ and $d$.

The additive effect depends on the reaction temperature. The higher the temperature is, the
Table 11 Comparative Economics Analysis Venezuela (MM\$ 1983) 100,000 BPSD

\begin{tabular}{l|ccc}
\hline Process Conversion & $\begin{array}{r}\text { Hydrovisbreaking } \\
88 \% *\end{array}$ & $\begin{array}{c}\text { H-Oil } \\
90 \%\end{array}$ & $\begin{array}{c}\text { Eureka } \\
75 \%\end{array}$ \\
\hline Operating Cost & 90 & 125.2 & 80 \\
Investment & $1,716.8$ & 2,000 & 1,598 \\
Gross Income & 740 & 740 & 441 \\
Cash Flow & 264.74 & 284.10 & 209.6 \\
TIR (PDVSA) \% & 12.5 & 11.8 & 10.8 \\
TIR\% (with Inflation) & 25.0 & 23.0 & 18 \\
-(PDVSA) \% & & & \\
\hline * Severity IV with recycle
\end{tabular}

lower the effect, since thermal reactions have a predominant effect. The economics and the operability of the process are largely improved by the additive when high residuum, asphaltene and sulphur feedstock ought to be upgraded.

A deeper study to determine if the additive plays a catalytic role is in progress.

\subsection{Economics}

Some preliminary economic evaluations are presented in order to assess the potential of this hydrovisbreaking technology. They were evaluated for a particular scenario in Venezuela (1983). High localization (1.34) and contingency factors (1.25) were used for capital investment.

The hydrovisbreaking scheme for $88 \%$ of residuum conversion is presented in Fig. 4. A mass balance for 100,000 BPSD refinery is also shown there. Table 11 shows a comparative economic analysis among the hydrovisbreaking process, a high conversion hydrocracking process $(\mathrm{H}-\mathrm{Oil})$ and a "coking" process (EUREKA). All are placed in an integrated refinery where some hydrotreating facilities are available for distillate desulfurization. For the three processes considered, downstream upgrading is fixed in order to obtain the same product quality shown in Fig. 4 (S, N, CRG and unsaturates). Hydrovisbreaking, which uses conventional coil+soaker reactor and a decanting stage, rejects only $6 \%$ of soild material. This material contains more metals than any other process pitch (Vacuum residuum), and, therefore, it has the lowest commercial value. The capital investment and operating cost for hydrovisbreaking are intermediate between those of the $\mathrm{H}-\mathrm{Oil}$ and EUREKA processes.

The Internal Rate of Return (TIR) with and without inflation, is similar for the H-Oil and Hydrovisbreaking processes, and both processes appear to be more profitable than the Eureka process.

\section{Conclusions}

The results obtained in this work show that : 


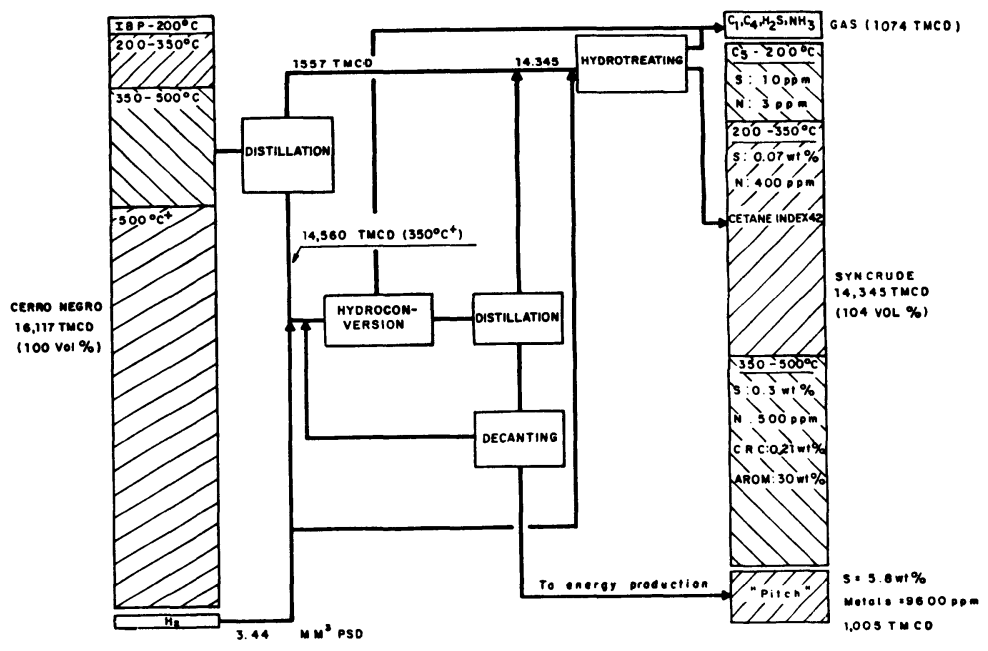

Fig. 4 Hydrovisbreaking Scheme

1) For low hydrovisbreaking severity, a coil+ hydrogenation technology could be used. The syncrude obtained is a medium quality transportable heavy oil. Low investment operating cost is required for this upgrading.

2) Using coil +soaker + decanter technology, a high conversion could be achieved. The syncrude produced contains high quality distillates useful for a conventional refinery. The syncrude has a $32^{\circ}$ API, $0.4 \%$ of sulphur, no metal content. It is produced by a scheme of $88 \%$ conversion of the $500^{\circ} \mathrm{C}+$ fraction.

3) The high conversion hydrovisbreaking technology is a competitive process with intermediate capital investment and operating cost. It uses conventional equipment operating at high pressure and high temperature and a cheap additive which controls thermal degradation reactions.

\section{Acknowledgement}

The authors thank the Analytical Chemistry Department of INTEVEP for helpful contributions and to PDVSA for the permission to publish this work.

\section{Nomenclature}

ASPH : Asphaltene

AROM/MOL : Aromatic per mol

\author{
BPSD : Barrel per stream day \\ CST : Centistokes \\ DPDP : DPDP (Porphyrin) \\ DOS : Days on stream \\ ETHIO : ETHIO (Porphyrin) \\ HDM : Hydrodemetallization \\ HFT : Hot filtration test-L1 to L7 (Relative value \\ of stability) \\ HPHTS : High pressure high temperature separator \\ HPLTS : High pressure low temperature separator \\ IBP : Initial boiling point \\ NMR : Nuclear magnetic resonance \\ STDR : Stirred tank discontinuos reactor \\ TBP : True boiling point \\ TIR : Internal tax of return \\ VGO : Vacuum gas oil \\ VPO : Vapor pressure osmometry
}

\section{References}

1) Graeser, NIEMAN OGJ, March 1981.

2) Gulf, US Patent, 4, 294,686, October 13, 1981.

3) INTEVEP, US Patent, US 238344, February 26, 1981.

4) CANMET, Ganadian Patent 1073389.

5) Exxon, US Patent 4, 134, 825, February 16, 1979.

6) Mobil, US Patent 4, 203, 830, May 20, 1980.

7) UOP, US Patent, 4, 622, 503, November 23, 1971.

8) Lubkowitz et al., REV. TEC. INTEVEP, 2, (1) Jan., 13 (1981); ACS Preprint, New York Meeting, August 23-28, 839 (1981).

9) Galiasso, R., Blanco, R., Gonzalez, G., Quinteros, N., Fuel, Accepted for publishing (1983). 


\section{R. Galiasso, J. A. Salazar, R. Blanco, and A. Morales \\ INTEVEP, S. A., P.O. BOX 76343, Caracas 1070A, Venezuela}

石油精製において水素含有量の低い原料油から水素に富む油 を製造する方法の一つに水素化精製法がある。その中には $\mathbf{H}-$ Oil 法のように大量の触媒と複雑な技術を用いる方法がある が, 最近は水素供与性溶媒, 高圧水素, 特殊な触媒などを用い るハイドロビスブレーキング法が提案されている。本研究で は, 生成物の品質と液体収率を制御するために安価な添加物を 用いた新しい八イドロビスブレーキング法をベンチスケールで 検討した。

反応は, コイル反応器と水素化反応器および水素化脱金属反 応器を連結した方法 (Fig. 1A) とコイル反応器とソーカー反 応器を連結した方法 (Fig・1B) により行った。コイル反応器 の反応条件は一定で, その他の反応器については反応条件（シ ビアリティー）を変化させた（Table 3)。反応原料はセロネグ 口原油（性状は Table 1) あるいはその常圧残油 $\left(650^{\circ} \mathrm{F}^{+}\right.$, 性 状は Table 6) を用いた。

セロネグロ原油は金属，アスファルテン，蒸留残さの量が多 い超重質油である。そのままでは輸送できないので粘度を 120 cSt $\left(38^{\circ} \mathrm{C}\right)$ に下げる必要がある。この減圧残油は $\mathrm{N}, \mathrm{S}$ の含 有量が高く, $\mathrm{H} / \mathrm{C}$ 比が低い芳香族系の油である。減圧残油中 のアスファルテン分, レジン分, 油分の性状は Table 2 に示 されているが，金属は主にアスファルテン構造中に存在する。

Fig. 1A に示した反応方式によるハイドロビスブレーキング は低いシビアリティーI， IIに拈いて行った。コイル反応器の 条件はよく制御することが必要であり, 添加物と高圧水素の存 在により正常な運転が可能である。水素化反応器では, コイル 反応器で生成した不飽和分が 飽和され安定な生成物が得られ る。水素化反応用いられる INT - 2 触媒 (Table 4) は特殊な 細孔分布をもち, 分解された分子は細孔を通過できるが，アス ファルテンの拡散は制限される。INT -3 触媒は通常の水素化脱 金属触媒である。セロネグロ原油に関する反応結果は Tables 5, 7 に示されているが，コイル反応器で $500^{\circ} \mathrm{C}^{+}$留分の $30 \%$ が転化され, 主にディーゼル油になる。金属分, N分, S 分は 主に水素化段階, 脱金属段階で除去される。液収率は 96.0/ $96.5 \mathrm{wt} \%$ であり, 水素消費量は $70 / 162 \mathrm{Nm}^{3} / \mathrm{t}$ である。脱金 属反応器の方が, 水素化反応器と比べてアスファルテン. 金属, $\mathrm{S}$ の除去率が高い。これらの接触反応器ではコイル反応器での 転化率を少し増加させる。また，いずれのシビアリティーでも 粘度は急激に減少する。25 日間の連続試験を行った (Fig. 2) が，活性低下は見られなかった。使用後の触媒（Table 4) に は $7 \mathrm{wt} \%$ のが均一に蓄積していた。炭素析出により細孔容 積の $50 \%$, 表面積の $70 \%$ が失われるが，運転開始 2 日後の定 常活性には影響しない。シビアリティーI, II における生成油
は中程度の品質の輸送可能な重質油である。要求される投資額 は中程度 (Gulf HDS プロセスと同程度)である。

次に, コイル反応器の後に接触反応器の代わりにンーカー反 応器(バブルカラム型)を用いた場合 (Fig. 1B) について検討 した。原料は常圧残油を用いた。生成物は高圧高温分離器で分 離された後，大部分の VGO と残さを含む液状生成物は特殊な デカンターで処理され，不溶のアスファルテン分は除去され， 未反応物は再循環される。デカンターに入る前の生成物の性状 と転化率は Tables 6 と 7 に示した。生成油はシビアリティ 一 I, II で生成する油より低沸点留分が多く高品質である。液 収率は $96 \mathrm{wt} \%$ で， $500^{\circ} \mathrm{G}^{+}$留分の転化率 $67 \%\left(430^{\circ} \mathrm{C}\right)$ と $79 \%\left(450^{\circ} \mathrm{C}\right)$ に対する水素消費量は 125 と $150 \mathrm{Nm}^{3} / \mathrm{t}$ であ った。また，アスファルテンとコンラドソン炭素の転化率は約 50\% と 45\% であった。45 日間の長時間試験（Fig. 3) では, 円滑な運転ができ，生成物の性状は一定であった。シビアリテ ^ーN での 生成油の 各留分の性状（Table 9) を原油の性状 (Table 1) と比較すると,

（1）生成するナフサ留分は原油中のナフサ留分より重質で ある。 $\mathrm{S}$ 分は少なく，芳香族分と $\mathrm{N}$ 分が多い。

（2）生成するディーゼル油は原料中のディーゼル油より $\mathrm{S}$ 分, N分ともに多い。

（3）生成した VGO は原料中の VGO 上り重質で, N分, コンラドソン炭素, 不飽和分ともに多い。

(4) 生成する減圧残油は, 原料中のものより $\mathrm{S}$ 分, N分, コンラドソン炭素, アスファルテン分の含有量はいずれも高い が、水素含有量が低い。

添加物の効果をオートクレーブを用いてソーカー反応器と同 じシビアリティーで検討した。Table 10 に示すよらに，添加 物の使用は $500^{\circ} \mathrm{C}^{+}$留分, アスファルテンおよびュンラドソ ン炭素の転化率を上昇させ，ガス収率と不溶分の生成を減少さ せる。また, 留出油中のナフサの量を減少させ，ディーゼル油 の量を增加させる。水素化反応の速度は添加物によって促進さ れ, 生成油中の全水素量が増加し, 留出油, ガス中の不飽和分 量が少なくなる。したがって, 残さ, アスファルテン分および $\mathrm{S}$ 分の多い原料を精製する場合に添加物を使用すると，プロセ スの経済性と運転しやすさが大きく改善される。

残油転化率 $88 \%$ に対応したハイドロビスブレーキングの工 程図は Fig. 4 のようになるが，これと他のプロセスとの経済 的な比較は Table 11 に示したようになる。この結果から， 本報で述べたハイドロビスブレーキング法は H-Oil 法, ニリ カ法と競合できるといえる。

\section{Keywords}

Additive effect, Cerro Negro crude, Coil type reactor, Economics, Hydrovisbreaking, Soaker reactor 